全周記録・監視力メラ

長井勝正

\title{
Underwater Application of All Ranges Monitoring and Recording Device
}

by Katsumasa Nagai

Ocean Engineering Group NAC Incorporated

\begin{abstract}
Most preferably, underwater image recording device should cover as wider range as possible. This report explains $360^{\circ}$ panoramic all range recording system to photograph $360^{\circ}$ range of view which surrounds the camera at the centre, onto the sheet copy. The writer also makes mention of $360^{\circ}$ range monitoring device which utilizes TV camera as well. The photos which were obtained by means of above system, photographs of the inside surface of cylindrical structure or hole of boring, will be released.
\end{abstract}

フイルムカメラやTVカメラによる記録・監視はあ らゆるところで利用されているが，観たいところが観 られなかったり，観られても良く解らなかったりする 経験は誰でもあると思ら。それは被写体が遠かったり， 近か過ぎたり或いは人が近か付けない様な場所でしば しば起きる。ここで紹介する 2 つのカメラは各々共通 な特殊光学系を採用し, 水中の監視記録と, 試錐など ボーリングの内側を記録する所謂全周カメラを示す。 (写真 1,2 )

\section{水中への応用}

$\mathrm{TV}$ カメラやフイルムカメラによる水中映像情報の 収集については，一般に水深の浅いところではダイハ 一の手で，深いところでは施回架台をカメラに併用し ている。ここで問題となるのは従来用いている施回架 台は,カメラ自体を俯仰施回させる方法であるため, 簡 単な装置であっても非常に大きな構造となり, 駆動す る為の電源, ケーブルなど大容量のものが要求された。

ここに紹介する装置は小型で十分な俯仰施回を有す るもので, 特殊光学系を使用したレンズニニットで構 成されている。それは従来の様な架台を使用しないで, 固定二ニット内の光学系の一部に俯仰施回の機能を持 たせたものである。

\section{装置の概要（説明図 1 参照)}

装置以第 1 図に示す様にレンズの前面に配置したミ ラーの回転で施回を与兄ている。同様に俯仰方向の動

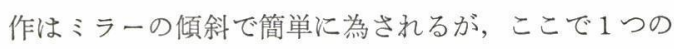
問題が生ずる。ミラーの回転による施回動作は映像自 体も回転軸を中心にして回転してしまう。そのため本 装置に於いては映像の回転を補正するために“PEC HAN”プリズムを採用した。PECHAN プリズムはミ

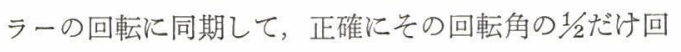

転し, その結果, 映像自体の回転は補正され(つまり 停止する), 施回だけが生ずる。ミラー及びプリズムの

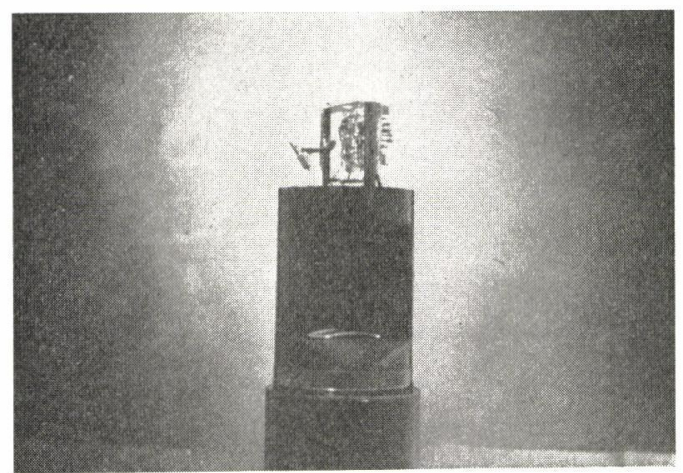

写真 1

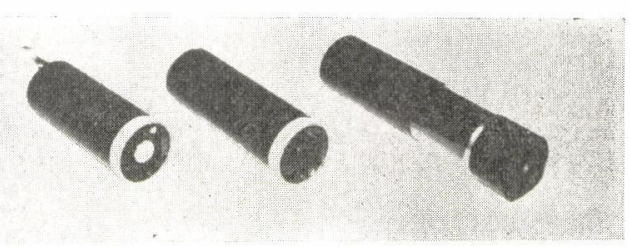

写真 2

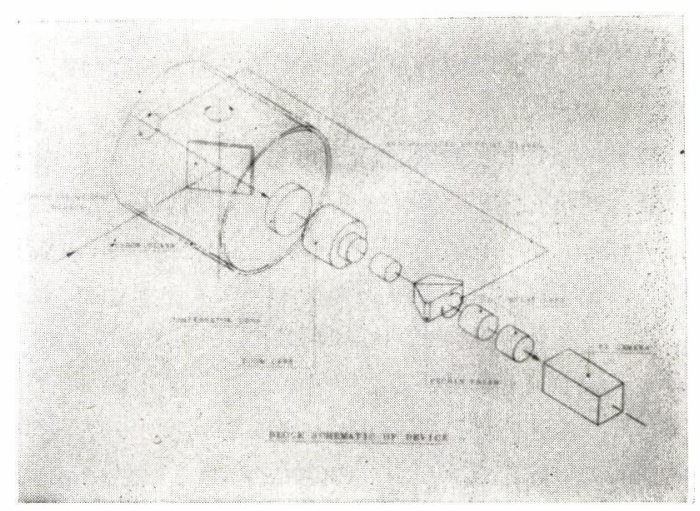

説明図 1 
回転駆動にはサーボメカニズムを採用しているが，前 述の如く従来のカメラボデイ本体を施回俯仰させる方 式と比較すると極端に小型, 軽量, 小消費電力化して いるのが大さな特色である。更に大気中での用途は勿 論, 水中での使用は特に従来方式は, 施回俯仰する部 分が (機械的部分) 直接水と接することによる幾多の 問題点が指摘されている。

施回俯仰の駆動制御はケーブルを通じて陸上又は海 面上の制御器で為されるが,この制御器は, ミラー及 びブルズムの施回俯仰制御と施回光学系 PECHANに 続くズームレンズのズーミング, フオーカシング, 及 びアイリスの制御をTVモニターを監視し乍ら行う。

なお本装置では示されていないが，LLL(LOW-

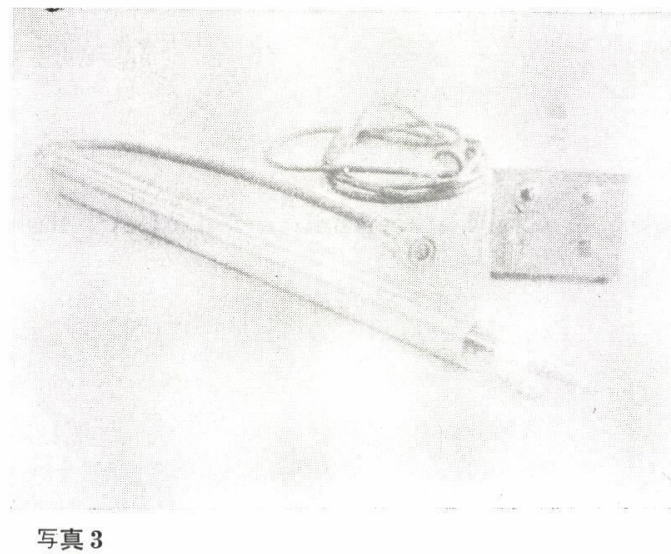
LIGHT-LEVEL) IMAGE INTESI FIER をズームレンズの後に配するこ とにより暗視野の撮像がコ能である。 主なる仕様

撮像 レンズ: $\mathrm{f}=20 \sim 60 \mathrm{~mm}$ ズーム $\mathrm{F} / 1.8$

施 回 角 度: $\pm 180^{\circ}\left(360^{\circ}\right)$

俯 仰 角 度: $\pm 30^{\circ}\left(60^{\circ}\right)$

角度停止精度: \pm 20 分

施回速 度: $10^{\circ}$ /秒 MAX.

接続映像機器: 黒白, カラー TVカ

メラ $16 \mathrm{~mm}$ 又は 35

$\mathrm{mm}$ フイルムカメラ

耐用 水 深 : $500 \mathrm{~m}$

実用 水 深: $200 \mathrm{~m}$
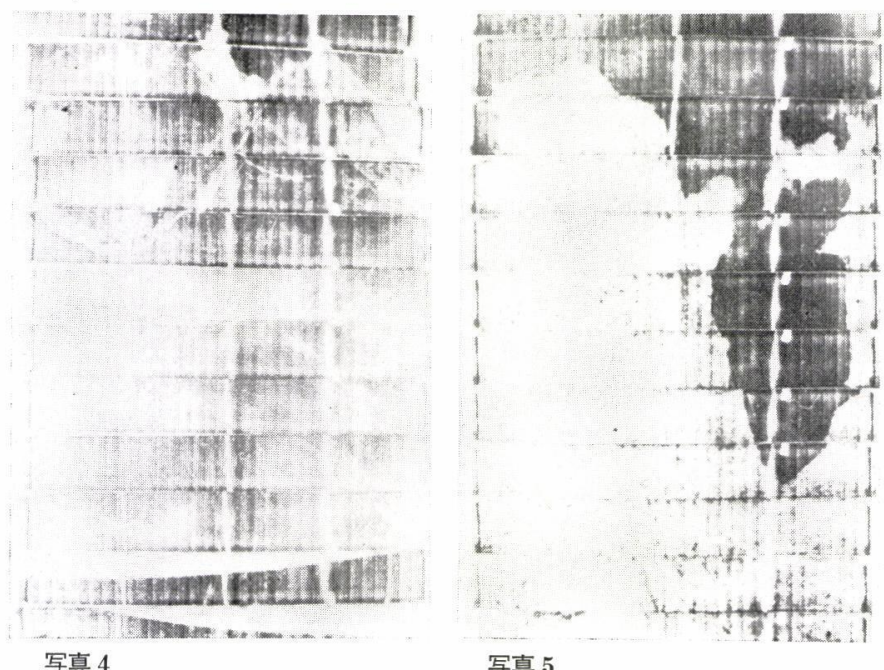

写真 5

制 御 機 能: 施回, 俯仰, ズーム, フォーカス, アイリス

プリセット制御： 6 ショット

マニュアル制御も可

\section{管内への応用}

地質調査で行らボーリング穴内壁, 鋼管など内筒形 状の内壁面の検查に有効な本装置ボアーホールカメラ は, 前項の水中 TVカィラの考光方之基本的には同じ である。

\section{装置の概要 (概観写真 3 参照)}

装置は第 1 図に示すミラ一の施回俯仰動作より俯仰 部を外し，TVカメラ部を $16 \mathrm{~mm}$ スリットカメラに置 換した全周 $16 \mathrm{~mm}$ スリットフイルムカメラである。

ミラーによる映像の回転は正確に PECHAN プリ ズムにより補正を受ける。フィルムはミラー及びプリ ズムの回転と同期して連続送りされている。フィルム の前面に配置したスリットの為に映像は 1 時的にスリ ットの幅の部分だけがフイルムに撮し込まれる。つま

りミラーの 1 回転で円筒状構造物の内壁面の連続した 画像の無歪な展開写真が得られる。(実写の例, 写真 4,5 )

\section{主なる仕様}

撮像レンズ: $\mathrm{f}=10 \mathrm{~mm} \quad \mathrm{~F} / 1.4$

使用フイルム: $16 \mathrm{~mm} 50$ フィート

周 回 時 間: 10秒/1回転

撮影可能 円筒：内径で $46 \mathrm{~mm} \phi$ 以上

耐水 性 : 20 気圧MAX.（水井戸の場合）

深度 : $100 \mathrm{~m}$

データ記 録: 方位指示マーク同時撮し込み

写真 2 の如く装置とケーブル $(100 \mathrm{~m})$, 及び地上設置 の制御器より構成され, 撮影毎にケーブルを必要量下 げて行く方式である。更に照明系がミラーの両側に配 置されて，1周毎フイルムの移動時間と同調する。

活動場所が山間僻地が多い為, 電源は $24 \mathrm{~V}$, バッテ リーで作動し, 商用電源の入力も可能である。 